University of Nebraska - Lincoln

DigitalCommons@University of Nebraska - Lincoln

Publications, Agencies and Staff of the U.S.

Department of Commerce

U.S. Department of Commerce

2009

\title{
Insights into the population structure of blue whales in the Eastern North Pacific from recent sightings and photographic identification
}

John Calambokidis

Cascadia Research Collective, calambokidis@cascadiaresearch.org

Jay Barlow

National Ocean and Atmospheric Administration, jay.barlow@noaa.gov

John K. B. Ford

National Ocean and Atmospheric Administration

Todd E. Chandler

Cascadia Research Collective

Annie B. Douglas

Cascadia Research Collective

Follow this and additional works at: https://digitalcommons.unl.edu/usdeptcommercepub

Part of the Environmental Sciences Commons

Calambokidis, John; Barlow, Jay; Ford, John K. B.; Chandler, Todd E.; and Douglas, Annie B., "Insights into the population structure of blue whales in the Eastern North Pacific from recent sightings and photographic identification" (2009). Publications, Agencies and Staff of the U.S. Department of Commerce. 247.

https://digitalcommons.unl.edu/usdeptcommercepub/247

This Article is brought to you for free and open access by the U.S. Department of Commerce at DigitalCommons@University of Nebraska - Lincoln. It has been accepted for inclusion in Publications, Agencies and Staff of the U.S. Department of Commerce by an authorized administrator of DigitalCommons@University of Nebraska - Lincoln. 


\title{
Insights into the population structure of blue whales in the Eastern North Pacific from recent sightings and photographic identification
}

\author{
John CALAmbokidis \\ Cascadia Research Collective, \\ Waterstreet Building, \\ $218^{1} / 2$ W. Fourth Avenue, \\ Olympia, Washington 98501, U.S.A. \\ E-mail: calambokidis@cascadiaresearch.org \\ JAY BARLOW \\ National Ocean and Atmospheric Administration, \\ Southwest Fisheries Science Center, \\ 8604 La Jolla Shores Drive, \\ La Jolla, California 92037 U.S.A. \\ JOHN K. B. FORD \\ Department of Fisheries and Oceans, \\ Pacific Biological Station, \\ Nanaimo, British Columbia V9T 6N7, Canada \\ TODD E. CHANDLER \\ AnNie B. Douglas \\ Cascadia Research Collective, \\ Waterstreet Building, \\ $218^{1} / 2$ W. Fourth Avenue, \\ Olympia, Washington 98501, U.S.A.
}

\begin{abstract}
Blue whales were widely distributed in the North Pacific prior to the primary period of modern commercial whaling in the early 1900s. Despite concentrations of blue whale catches off British Columbia and in the Gulf of Alaska, there had been few documented sightings in these areas since whaling for blue whales ended in 1965. In contrast, large concentrations of blue whales have been documented off California and Baja California and in the eastern tropical Pacific since the 1970s, but it was not known if these animals were part of the same population that previously ranged into Alaskan waters. We document 15 blue whale sightings off British Columbia and in the Gulf of Alaska made since 1997, and use identification photographs to show that whales in these areas are currently part of the California feeding population. We speculate that this may represent a return to a migration pattern that has existed for earlier periods for eastern North Pacific blue whale population. One possible explanation for a shift in blue whale use is changes in
\end{abstract}


prey driven by changes in oceanographic conditions, including the Pacific Decadal Oscillation (PDO), which coincides with some of the observed shifts in blue whale occurrence.

Key words: population structure, blue whale, Balaenoptera musculus, North Pacific, Alaska, Canada, movements, photo-identification.

Blue whales (Balaenoptera musculus) were widely distributed in the North Pacific prior to whaling. Shore-based and pelagic whaling vessels around the Pacific Rim took large numbers from northern Japan to northern Mexico from 1924 to 1965 (see fig. 1 in Rankin et al. 2006). Many authors have noted the apparent lack of recovery of blue whales in areas of the North Pacific, where they were previously common (Leatherwood et al. 1982, Rice and Wolman 1982, Stewart et al. 1987, Forney and Brownell 1996). Despite concentrations of blue whale catches off British Columbia, off southeast Alaska, in the Gulf of Alaska, and south of the eastern Aleutian Islands, there had been few documented sightings in those areas since the 1970s and an absence of sightings in surveys covering the exact areas where the blue whales had been taken in large numbers. In contrast to this, large concentrations of blue whales have been documented off California and Baja California and in the eastern tropical Pacific since the 1970s (Wade and Friedrichsen 1979, Calambokidis et al. 1990, Reilly and Thayer 1990, Barlow 1994, Calambokidis and Barlow 2004). Rice (1974) originally suggested that blue whales in the eastern North Pacific migrated between Baja California, California, the Gulf of Alaska, and the eastern Aleutian Islands; however, he subsequently concluded that blue whales in California and the Gulf of Alaska belonged to separate populations (Rice 1992). Stafford et al. (2001) noted that North Pacific blue whales can be divided into putative eastern and western populations based on differences in acoustic call types, but found geographic overlap in these call types in the central North Pacific. Stafford (2003) found both call types in the Gulf of Alaska.

Here, we document 15 blue whale sightings off British Columbia and in the Gulf of Alaska that have been made since 1997, and use identification photographs to show that whales in these areas are currently part of what has been recognized as the California feeding population. We speculate that this represents the reestablishment of a traditional migration pattern for an eastern North Pacific blue whale population.

\section{METHODS}

Sightings and identification came from two different types of surveys and one opportunistic observation. Annual surveys of 6 to $10 \mathrm{~d}$ were conducted jointly by Cascadia Research and the Canadian Department of Fisheries and Oceans (DFO) each August from 2003 to 2007. Waters off northern Vancouver Island north to the southern Queen Charlotte Islands were surveyed using two ships, a converted North Sea trawler (Curve of Time) in 2003-2006 and a DFO research ship (John P. Tully) in 2007. Both ships carried two rigid-hull inflatable boats, which were deployed for photo-identification and biopsy sampling of individual whales. These surveys included waters west of Cape Scott and off south Moresby Island, the principal areas blue whales were taken during commercial whaling off British Columbia in the 
mid 1900s (Pike and MacAskie 1969, Gregr and Trites 2001). Blue whales were sighted in 4 of the $5 \mathrm{yr}$ these surveys were conducted with identification photographs obtained of all 10 individuals encountered (Table 1).

In summer and fall of 2004, the Southwest Fisheries Science Center (SWFSC) conducted a cetacean survey along the Pacific Rim from southern British Columbia to the western Aleutian Islands. The primary focus of this survey was to obtain identification photographs and biopsies from humpback whales as part of the SPLASH (Structure of Populations, Levels of Abundance, and Status of Humpbacks) research program. The survey was designed to cover the regions of current and historic humpback whale concentrations. Transect lines were generally within 50-100 km of the coast in most regions but extended to approximately $500-\mathrm{km}$ offshore between Prince William Sound, Alaska, and Umnak Island in the eastern Aleutians. There were sightings of six blue whales during the 2004 surveys in Alaska with good identification photographs taken of five of these animals (Table 1).

Identification photographs obtained from Alaska and British Columbia were compared to the catalog of 1,955 individual whales identified primarily from 1986 to 2006 off the U.S. west coast and extending south to the eastern tropical Pacific (Calambokidis et al. 1990, Calambokidis and Barlow 2004). Identification photographs consisted of left and/or right sides of blue whales showing the pigmentation patterns on the sides of the animal in images that include the dorsal fin. Photographic matching was conducted by eye using photographic prints of whales and was stratified into seven categories for blue whale identifications based on color patterns and dorsal fin condition.

\section{RESULTS}

Blue whales were seen in 4 of the 5 years survey were conducted off British Columbia (2003, 2005, 2006, and 2007). Only one or two blue whales were seen in the first three surveys, but, in 2007, five blue whales were seen on $1 \mathrm{~d}$ and three the following day (Table 1). This included one sighting of a mother and calf. All of the sightings except in 2007 were made off the southwestern side of the Queen Charlotte Islands within $10 \mathrm{nmi}(18.5 \mathrm{~km})$ of shore (Fig. 1, 2). The sightings in 2007 were all 30-40 nmi $(56-74 \mathrm{~km})$ SSW of the south tip of the Queen Charlotte Islands, an area that was only surveyed in 2007 and not in the previous August surveys.

In total, 10 blue whales were photographically identified off British Columbia including one from June 1997 (obtained opportunistically by a nature-trip operator, Randy Burke). Identification photographs revealed that the three whales seen on 12 August 2007 had all been seen the previous day when five total whales were identified. Three of the whales identified off British Columbia were animals that had also been seen off California (Fig. 3). One of these was seen in both British Columbia and California in the same year. That individual moved from off the Queen Charlotte Islands on 12 June 1997 to the Santa Barbara Channel on 10 July 1997. This represents a minimum distance of $1,347 \mathrm{nmi}(2,495 \mathrm{~km})$ covered in a maximum time of $28 \mathrm{~d}$. The minimum average swimming speed for such a transit is just over $2 \mathrm{~km} / \mathrm{h}$. This whale was sighted again a few days later on 14 July 1997 just west of the Santa Barbara Channel. This whale was also identified in other years, off southern and central California in August-September 1995 and July-September 1998. 


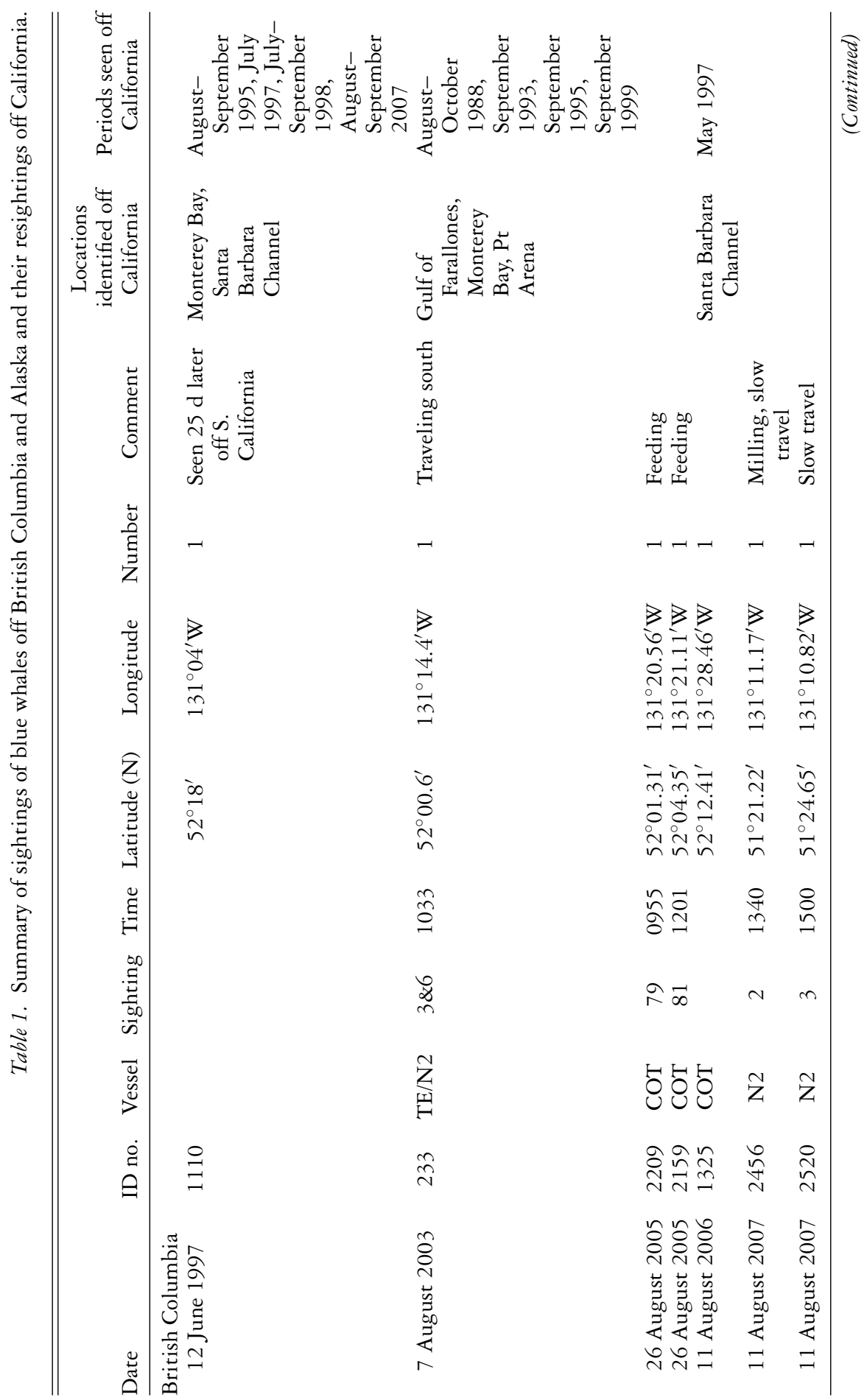




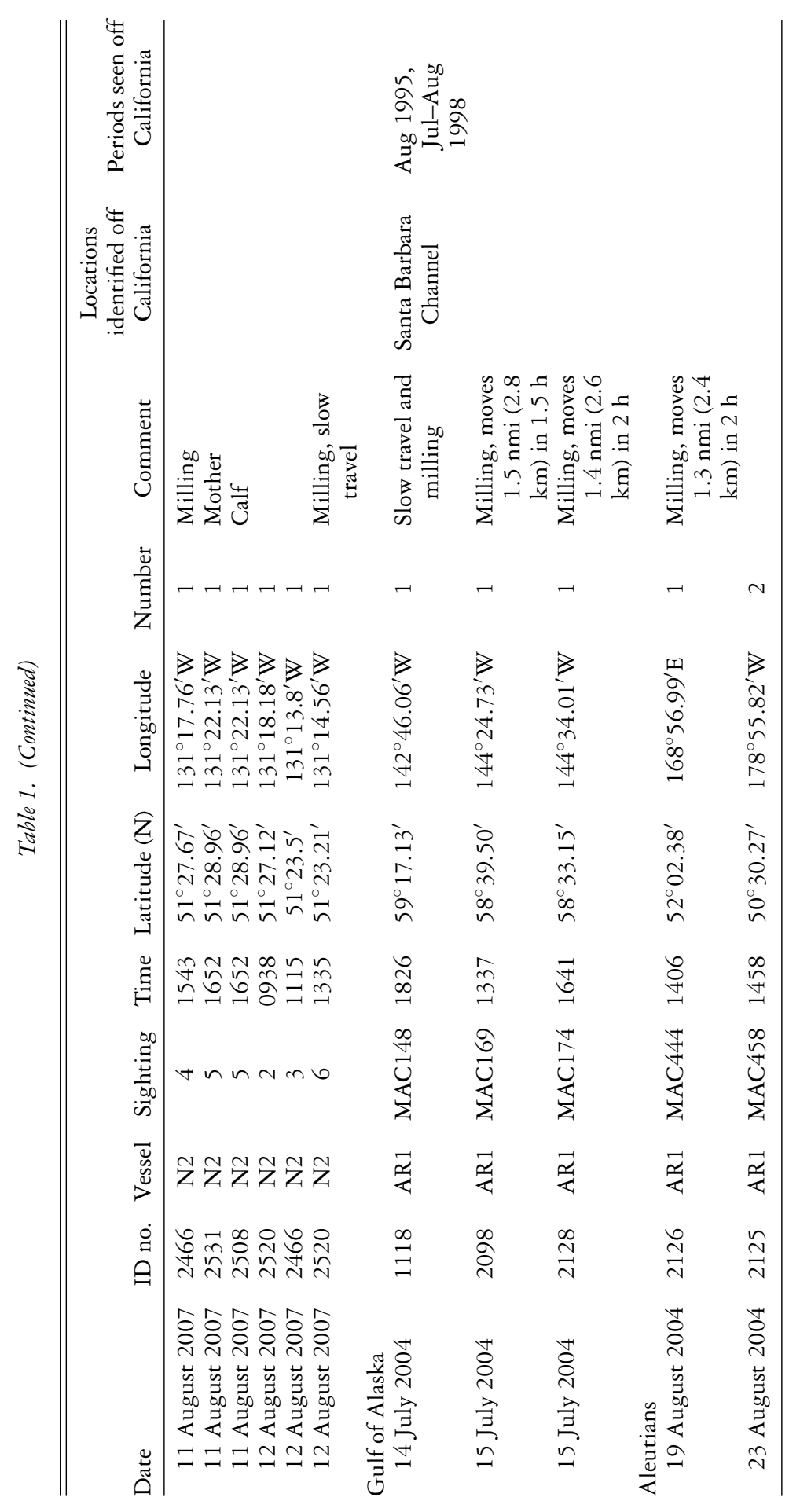




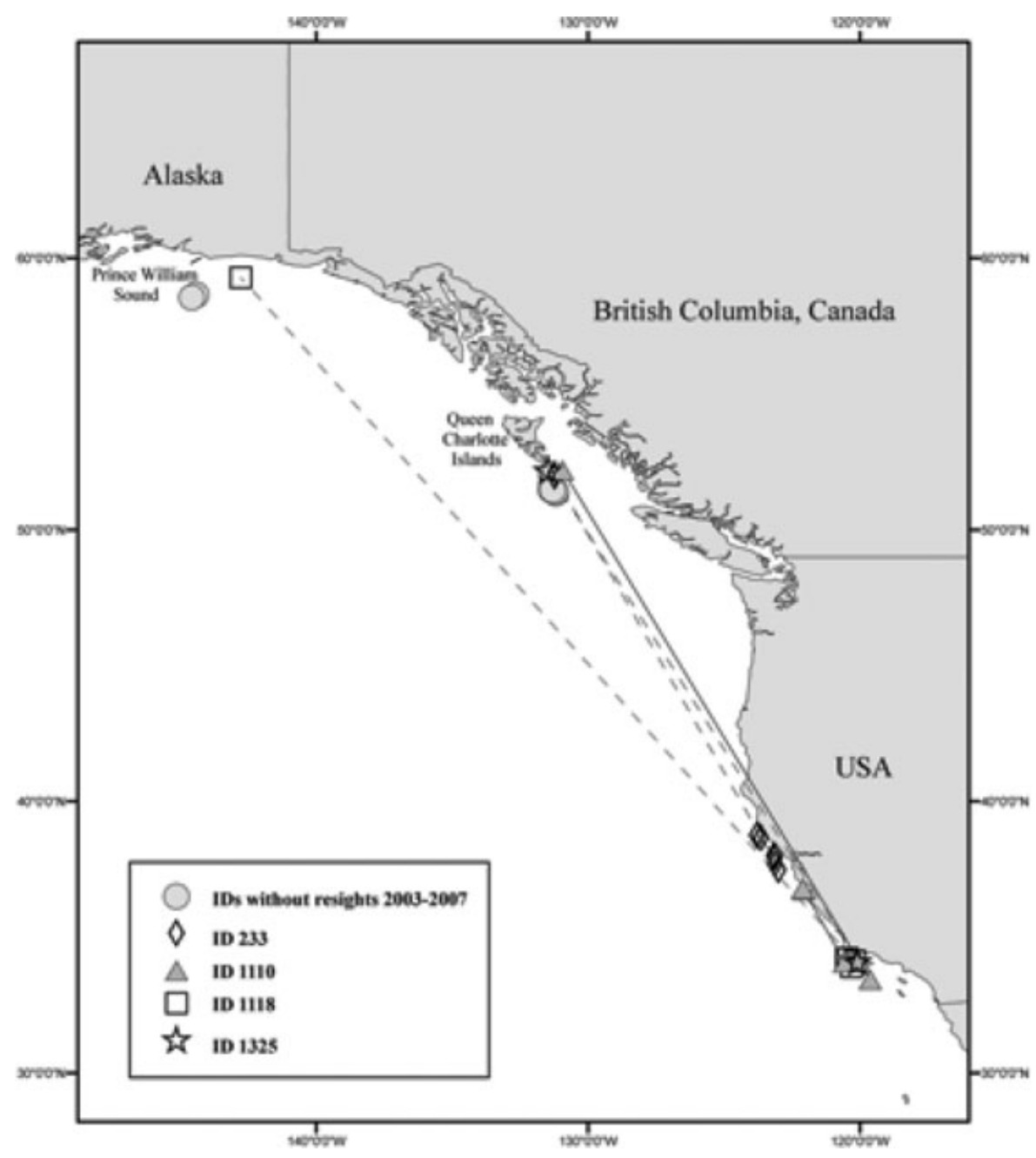

Figure 1. Locations of blue whales identified off British Columbia and in the Gulf of Alaska and their resighting locations off California. Circles show locations of animals identified that did not match California and other symbols show each of the four identified whales that had resightings with solid lines that connect resightings in the same year and dashed lines that connect sequential resightings across years. Sightings off the Aleutians (which did not match California) would be to the west of this map.

The two other blue whales identified off both British Columbia and California had been seen in those areas only in different years (Fig. 1). One of these, identified in August 2003 off British Columbia, had been identified seven times in August to October of 1988, 1993, 1995, and 1999, all near the Gulf of the Farallones off central California. The other was identified off British Columbia in 2006 and had been identified previously in May 1997 in the Santa Barbara Channel in the Southern California Bight. 


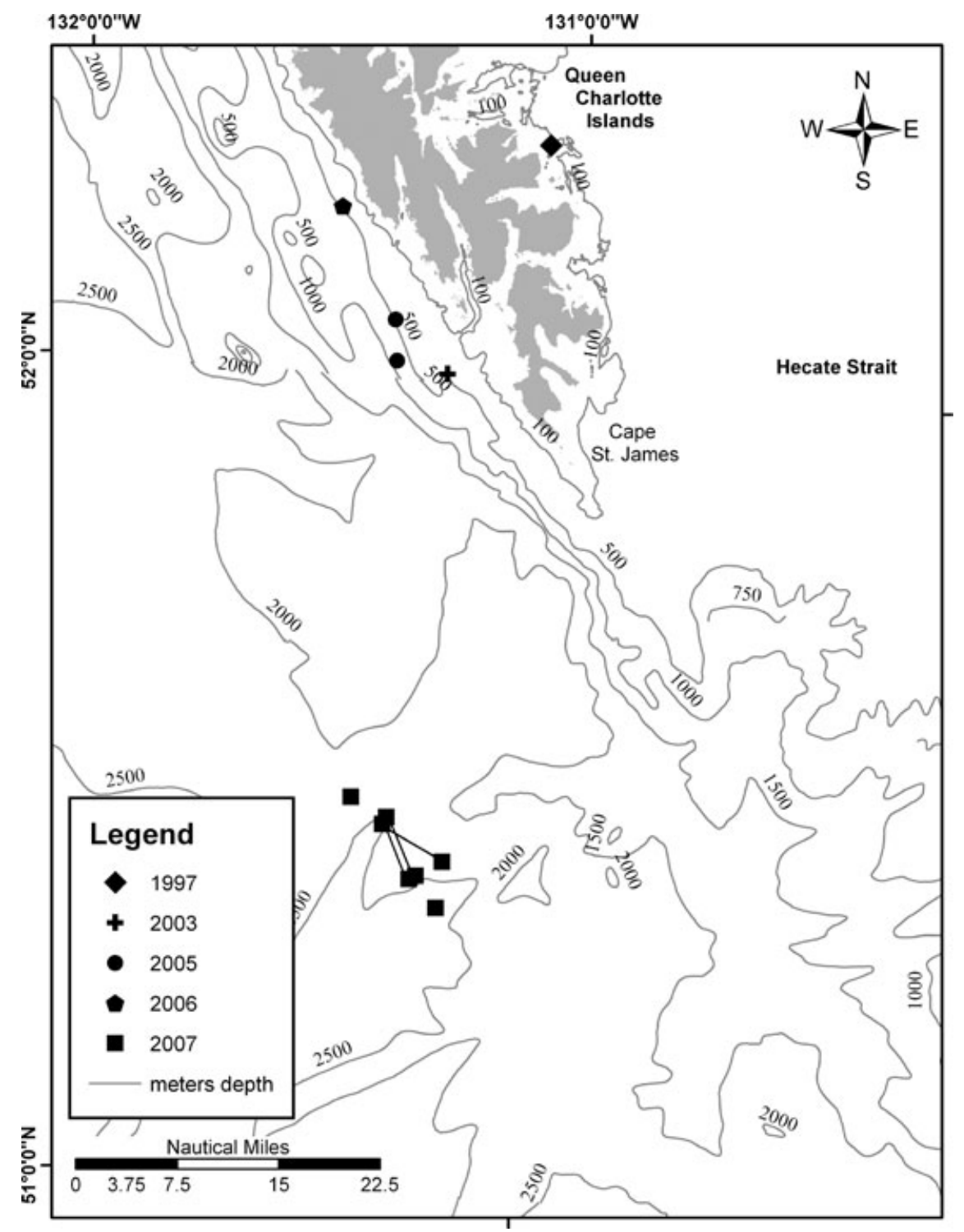

Figure 2. Locations of blue whale sightings and identifications in British Columbia. Lines connect multiple sightings of the same individuals in 2007 across $2 \mathrm{~d}$.

Three blue whales were photographically identified in the northern Gulf of Alaska on 14 and 15 July during the 2004 SWFSC cruises. These three sightings were all within $71 \mathrm{nmi}(131 \mathrm{~km})$ of each other and were less than $100 \mathrm{nmi}(185 \mathrm{~km})$ offshore between Yakutat and Prince William Sound (Fig. 1). One of these three had been identified previously off California. It had been seen five times on 3 different days in July and August of 1995 and 1998, all in and near the Santa Barbara Channel off southern California. 


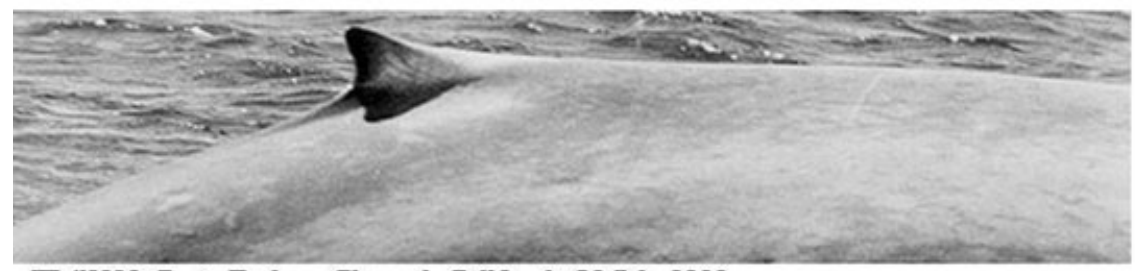

\section{ID H1118, Santa Barbara Chamed, Califomia 30 July 1998}

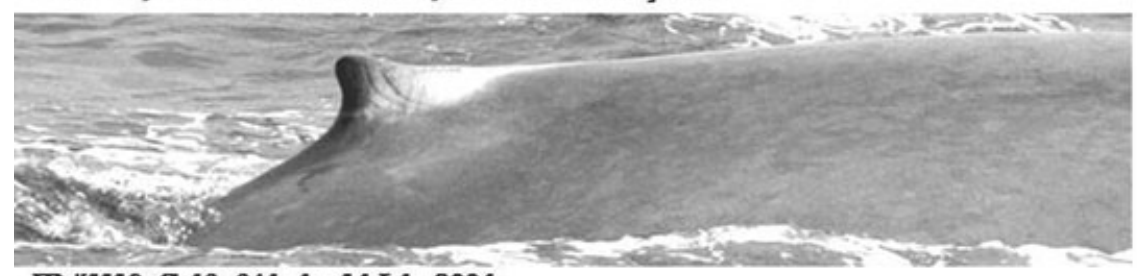

ID \#1118, Gulf of Alaska 14 July 2004

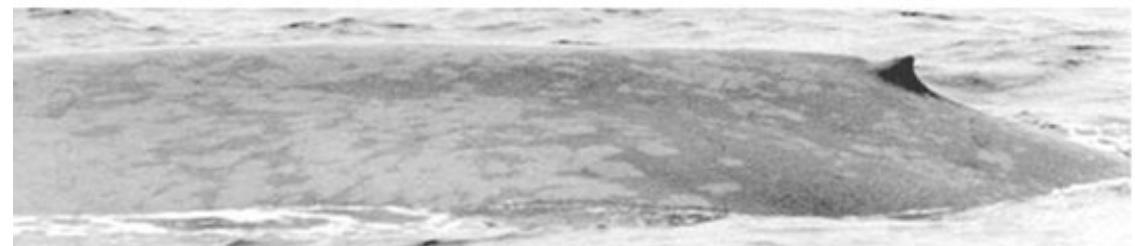

\section{ID $\# 233$, off Bodega Bay, Califormia 14 July 2004}

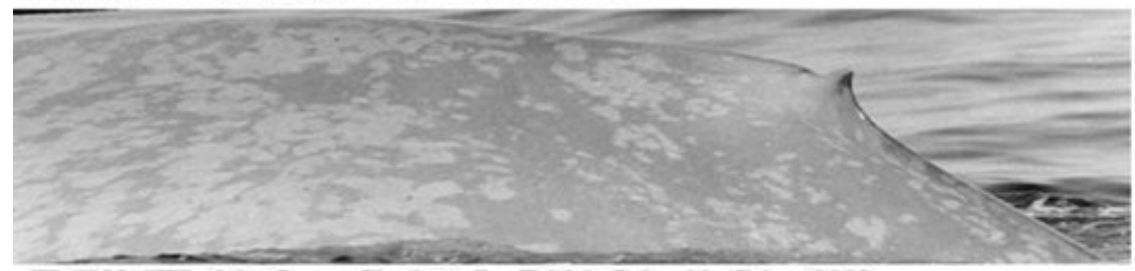

ID \#233, SW of the Queen Charlotte Is, British Columbia 7 Ang 2003

Figure 3. Identification photographs showing match between blue whales seen in Alaska and California (top two photos) and between British Columbia and California (bottom two photographs). Photographs by JC, TEC, and Siri Hakala, SWFSC.

Three blue whales were also seen off the Aleutian Islands, over 2,000 km west of those discussed in this paper, during the 2004 SWFSC cruise (Table 1). Two of these were identified photographically, but neither had been identified previously. The specifics of these sightings and the findings based on acoustics that these animals were part of the western North Pacific blue whale population are discussed in Rankin et al. (2006).

The percentage of photo-identified blue whales in these areas that match to a 1986-2005 catalog of individuals identified off California (31\% or 4 of 13 whales) indicates they are part of the same population. The proportion of whales from British Columbia and Alaska matching our catalog is biased downward slightly by the fact that five of the identifications were very recent (2007) and included a calf and a rather poor-quality photograph of the mother, all making it less likely they would match to our historical catalog. 


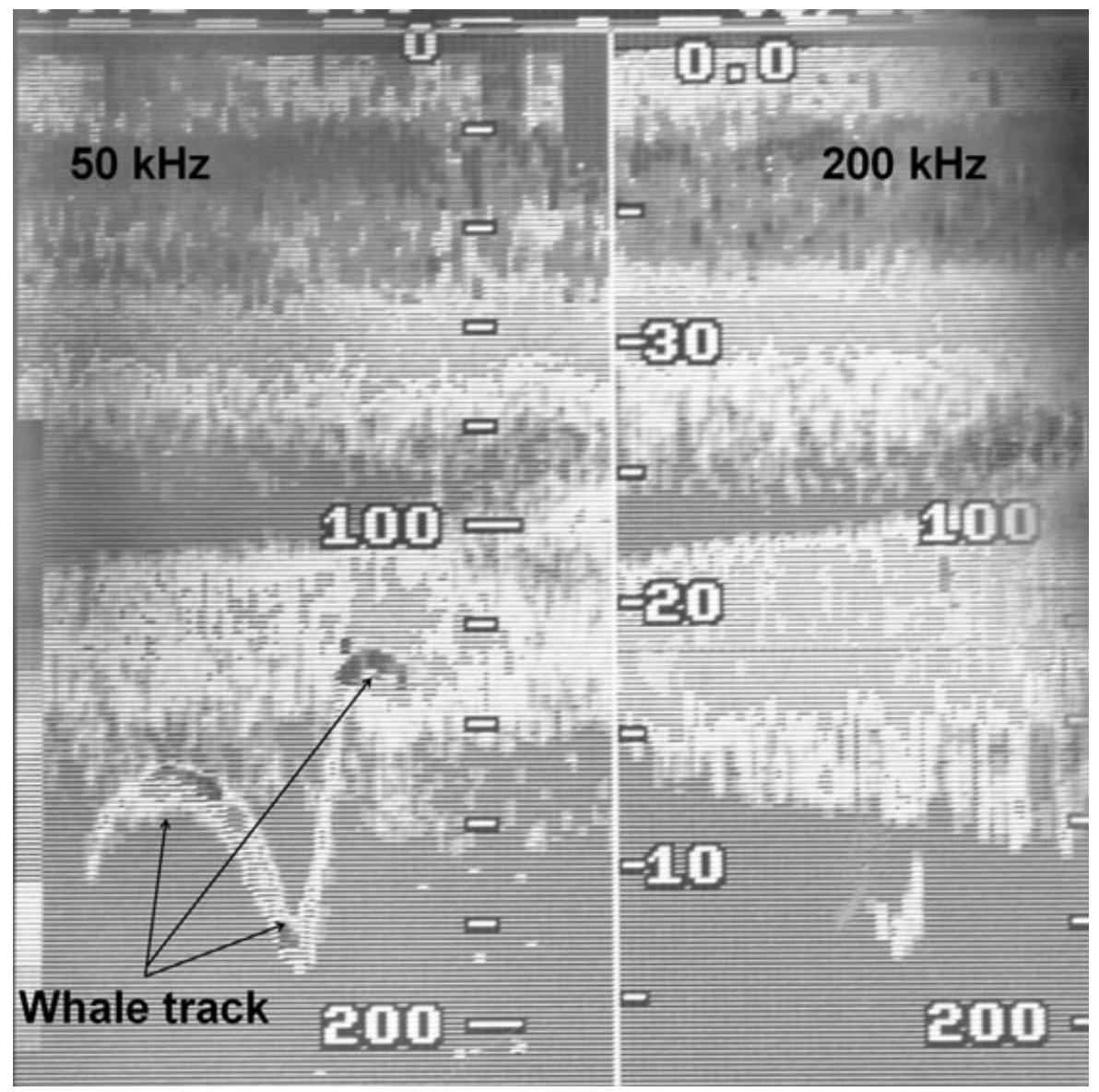

Figure 4. Image from split-frequency echo-sounder $(50 / 200 \mathrm{kHz})$ taken off the Queen Charlotte Islands on 26 August 2005 showing the prey layer (stronger on $200 \mathrm{kHz}$ ) at 100 $150 \mathrm{~m}$ and whale tracks (on $50 \mathrm{kHz}$ ) making upward movements from $190 \mathrm{~m}$ into prey layer.

The behavior of blue whales seen off British Columbia and in the Gulf of Alaska indicated that many of the animals were feeding. This was clearest in the three sightings off British Columbia in 2005 and 2006 where the animals were milling in one area, and a $50 / 200 \mathrm{kHz}$ echo sounder revealed a clear layer with strongest returns on $200 \mathrm{kHz}$ suggesting krill rather than fish (Simmonds and MacLennan 2005). In 2005 , we saw clear simultaneous tracings of both prey (on the $200 \mathrm{kHz}$ sounder) and the blue whale (on the $50 \mathrm{kHz}$ sounder) (Fig. 4). These showed the prey layer at 100 $160 \mathrm{~m}$ and the blue whale diving down to as deep as $200 \mathrm{~m}$ and then making at least two vertical excursions in the deeper or middle portion of the krill layers. These types of vertical excursions are typical of blue whale lunge feeding at depth revealed from tag data (Croll et al. 2001, Acevedo-Gutierrez et al. 2002, Calambokidis et al. 2007). In the two other sightings off British Columbia, blue whales appeared primarily to be traveling, and in one case (the 1997 sighting) the animal traveled southbound and was 
later resighted off California less than a month later. The blue whales seen in 2007 on two different days showed they were staying in the same area. All four sightings on 11 August and the resighting of three of these same animals on 12 August were all within an area that spanned less than $15 \mathrm{nmi}(28 \mathrm{~km})$. The three blue whales in the Gulf of Alaska were milling, in two cases moving only 1.5 and $1.4 \mathrm{nmi}(2.8$ and $2.6 \mathrm{~km})$ in the 1.5 and $2 \mathrm{~h}$ monitored, respectively, as is typical of feeding blue whales. Similarly, in one of the sightings in the Aleutians, the blue whale moved $1.3 \mathrm{nmi}(2.4 \mathrm{~km})$ in $2 \mathrm{~h}$.

\section{DISCUSSION}

The recent sightings and photographic matches that we report here have changed our view of blue whale population structure in the eastern North Pacific. We had previously considered the population of blue whales that feed off California to be separate from the population of whales that had historically inhabited the waters off British Columbia and in the Gulf of Alaska. Although the sample size is small, the number of matches does indicate that blue whales seen off British Columbia and at least in the eastern Gulf of Alaska are likely part of the same population that is seen off California.

We are not the first to suggest that blue whales move between feeding areas in California, British Columbia, and the Gulf of Alaska. Rice (1974) suspected blue whales occurring along the Baja coast in early spring migrated north, reaching British Columbia in May and then continuing north to the Gulf of Alaska. This was also supported by a Discovery tag recovery revealing movement of a blue whale marked off Vancouver Island to an area off Kodiak Island, $957 \mathrm{nmi}(1,772 \mathrm{~km})$ distant, a year later (Ivashin and Rovnin 1967). These animals presumably returned to the California coast in fall prior to their migration to southern waters. In recent years, however, a number of lines of evidence convinced many whale researchers including Rice (1992) that the population of blue whales that feeds in California was separate from those seen farther north. Blue whale abundance off California appeared to be increasing (Barlow 1994) at a time when blue whales were rarely, if ever, seen off Alaska and British Columbia (Rice and Wolman 1982; Reeves et al. 1985; Brueggeman et al. 1987, 1988; Ford et al. 1994; Forney and Brownell 1996). Blue whales were also not encountered in extensive aerial surveys off Oregon and Washington in 1989 and 1990 (Green et al. 1992) although they were detected acoustically in the early 1990s off Washington (McDonald et al. 1994). Significant differences were reported in the lengths of blue whales caught off Alaska in commercial whaling and those caught or measured from aerial photographs off California (Steiger et al. 1989, Gilpatrick and Perryman 2008). Also, the California blue whales carry warm water epizoites (including remora, barnacles, and copepods) that are not present on baleen whales that migrate to more northern colder waters (Rice 1992).

Our observations are consistent with recent acoustic recordings made from bottommounted hydrophones. Although blue whales in the North Pacific were originally considered part of a single management unit (Donovan 1991), acoustic data on call types have revealed at least two distinct patterns of blue whale vocalizations associated with eastern and western parts of the North Pacific (Thompson and Friedl 1982, Stafford and Fox 1998). The eastern call type is the only blue whale call type recorded off California, Oregon, and Washington (Stafford et al. 2001). Stafford (2003) reports 
detecting both the eastern and western North Pacific call types of blue whales in the Gulf of Alaska, indicating there may also be some areas where the distribution of these two populations overlaps. If these stereotypic calls are accurate indicators of population structure, then these observations also link California blue whales to those found in the Gulf of Alaska. Stafford (2003) found the highest proportion of eastern North Pacific blue whale calls at hydrophone locations farthest east, a little over $500 \mathrm{~km}$ off British Columbia, while hydrophones in the western portion of the Gulf of Alaska, SW of Kodiak, had a higher proportion of western blue whale calls.

Our findings of no matches to the two blue whales from off the Aleutian Islands is consistent with these animals being part of the western North Pacific blue whale population, and this conclusion is further supported by recordings of the western call type near these animals (Rankin et al. 2006).

Perhaps the most parsimonious explanation of these discordant lines of evidence is that blue whale migration patterns change in different oceanographic conditions. Although there are not similar surveys conducted across these time periods, there is circumstantial evidence for shifts in the relative abundance of blue whales having occurred between British Columbia/Gulf of Alaska and California. Blue whales in the eastern North Pacific were primarily killed in commercial whaling through 1966 in British Columbia and Alaska waters (Pike and McAskie 1969, Rice 1974, Gregr and Trites 2001) and relatively few were taken from whaling stations off California (Rice 1974, Clapham et al. 1997). Even after the end of commercial whaling for blue whales in 1965, the species continued to be sighted into the early 1970s in British Columbia and Alaskan waters in Japanese whale scouting expeditions (Wada 1980). Since 1980, however, a lack of blue whales has been documented on some of these former whaling grounds in Alaska (Rice and Wolman 1982; Reeves et al. 1985; Brueggeman et al. 1987, 1988; Forney and Brownell 1996) that contrasts to the evidence for a large increase in the number of blue whales sighted during surveys off California between 1979/1980 and 1991 (Barlow 1994) as well as other reports of increasing sightings of blue whales off California during that period (Dohl et al. 1983; Webber and Cooper 1983; Szczepaniak and Weber 1985; Smith et al. 1986; Rondeau 1987; Calambokidis et al. 1989, 1990; Pyle and Gilbert 1996). A potential recent shift back to common use of northern waters by blue whales may have taken place with the sightings and matches we report here (all since the late 1990s) that coincides with an apparent decrease in the number of blue whales occurring off California. Barlow and Forney (2007) reported a dramatic decrease in estimated abundance of blue whales from line-transect surveys off California from over 1,900 in each of the surveys in 1991, 1993, and 1996 to fewer than 700 in the surveys in 2001 and 2005.

Blue whales are clearly capable of long-range movements in search of prey. Satellite track and photographic-identification data have shown that they migrate in winter to productive areas of the eastern tropical Pacific to feed, including the Costa Rica Dome and areas off Baja California, Mexico ( Calambokidis et al. 1990, Reilly and Thayer 1990, Mate et al. 1999). In our own photo-identification data, we have records of individuals making north/south excursions that cover the length of California multiple times in one feeding season (Cascadia Research, unpublished data). It is likely that, whenever feeding conditions are inadequate in California, blue whales explore for and exploit resources in traditional feeding areas outside this region, including areas farther north. 
One possible explanation for a shift in blue whale habitat use would be shifts in prey availability driven by changes in oceanographic conditions. A number of related indices of climatic and oceanographic conditions for the Pacific Ocean have been developed that have been shown to affect abundance of both zooplankton and apex predators including marine mammals (Benson and Trites 2002). The impact of these oceanographic regime shifts on marine mammal populations has been complicated by changes in human impacts and interspecies interactions. For example, prey switching by killer whales as a result of whaling-induced decreases in large whale abundance through the 1960s has been cited as the cause for dramatic declines in pinniped populations in the North Pacific (Springer et al. 2003), although this hypothesis has been challenged by a number of authors (e.g., DeMaster et al. 2006, Wade et al. 2007) including Trites et al. (2007) who suggest an alternate hypothesis that these changes were the result of a regime shift in 1977.

Similar changes in oceanographic conditions and prey has been documented off California and along the west coast of North America associated with the Pacific Decadal Oscillation (PDO). Abundances of some euphausiid species off Southern California are correlated with the PDO (Brinton and Townsend 2003). Changes in oceanographic conditions and prey off California have had impacts on populations of krill-feeding seabirds (Hyrenbach and Veit 2003), and low levels of krill in some areas of the U.S. west coast in 2005 and 2006 were attributed as the cause of low levels of reproduction in Cassin's auklets (Sydeman et al. 2006). Although the timing of these events suggests a potential link between blue whale distribution and broader changes in oceanographic conditions and various marine species, the full implications of the PDO on densities of prey of blue whales both off California and the northern feeding areas off British Columbia and Alaska are not clear.

The timing of the PDO coincides with some observed shifts in blue whale historical takes during whaling. Even though takes of blue whales in commercial whaling in the eastern North Pacific varied with changes in location and amount of effort (as well as with the depletion of whale populations), there were also indications that these coincided with some of these shifts in the PDO regime especially off British Columbia (Fig. 5). The PDO cycle has been summarized as representing just two full shifts in the last century with "cool" regimes from 1890 to 1924 and from 1947 to 1976, and beginning again around 1998 and "warm" regimes from 1925 to 1946 and 1977 to the mid 1990s (Mantua and Hare 2002). The best long-term record is from commercial whaling off British Columbia that took over 1,300 blue whales over an extended period from 1908 to 1965 (Nichol et al. 2002). Largest numbers of blue whales were taken primarily during the "cool" water periods especially from 1908 to 1924 (total of 1,030 taken), it decreased for most of the "warm" regime period (total of 144 taken from 1925 to 1946), and then it increased again in the early 1950s through the end of whaling in 1965 (total of 204 taken from 1947 to 1965) (Nichol et al. 2002). Catches of just over 800 blue whales off Akutan also peaked from 1917 to 1924 during the "cool" PDO regime years, although the 218 taken off Pt. Hobron in the western Gulf of Alaska were highest in the 1930s and did not match this pattern (Brueggeman et al. 1985). Both these sites are west of the locations where we sighted blue whales and therefore may more likely reflect western North Pacific blue whales based on Stafford (2003). Kills of just under 1,000 blue whales off the west coast of Baja California, Mexico, primarily occurred in the spring and summer from 1926 to 1935 (Rice 1966) coinciding with the "warm" PDO regime. The virtual absence of blue whales (only three) taken off California by whalers operating out of Trinidad and Moss Landing from 1919 to 1926 (during 


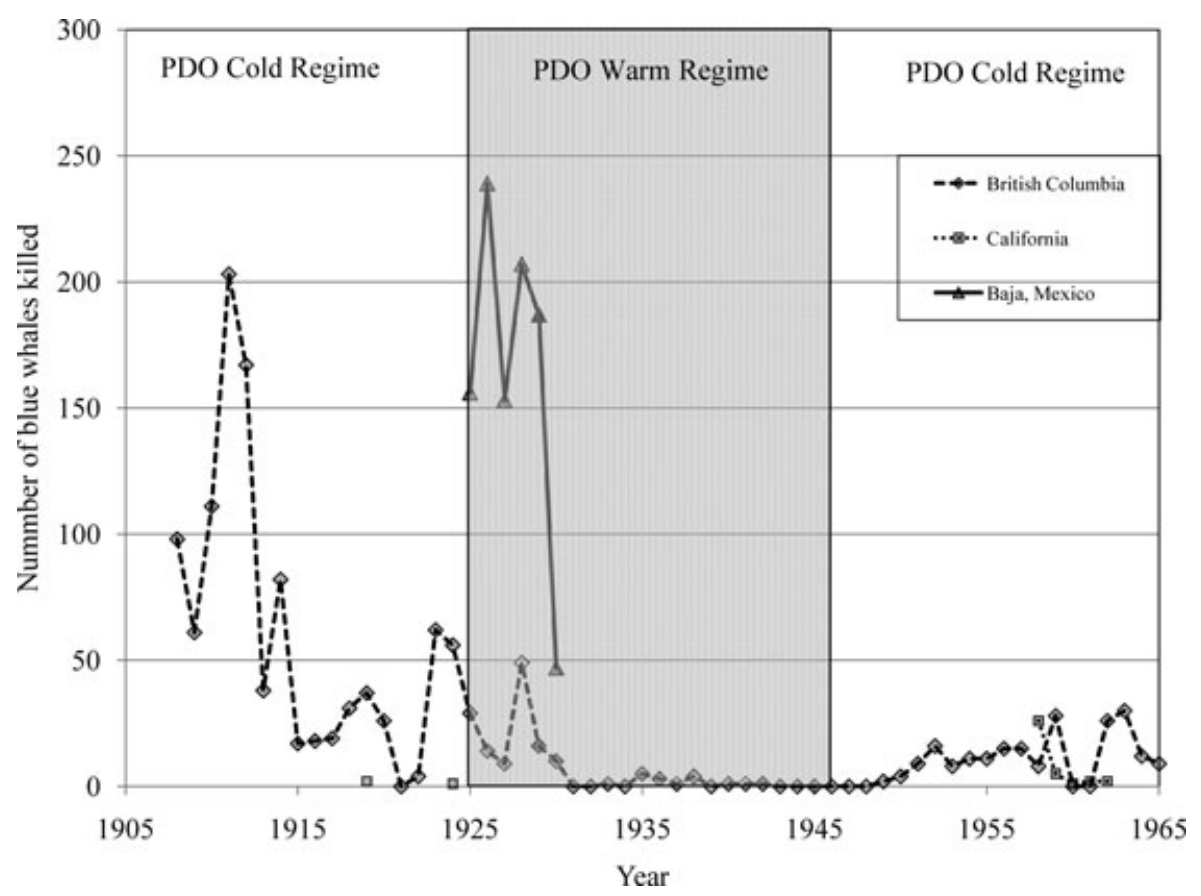

Figure 5. Number of blue whales killed off Mexico, California, and British Columbia (from Rice 1963, 1966; Clapham et al. 1997; Nichol et al. 2002) in relation to PDO cycles (from Mantua and Hare 2002).

the PDO cold regime) despite their frequent occurrence in those areas in the 1990s puzzled Clapham et al. (1997). Similarly whaling operations out of San Francisco Bay in the 1950s and 1960s only took about 33 blue whales (Rice 1963). Although a perfect fit would not be expected given the intermittent nature of some of these operations and the likely depletion of whale numbers, the overall pattern is generally consistent with: (1) primary takes of blue whales off British Columbia and some areas of Alaska during the "cool" PDO regime period and (2) lower whaling takes off British Columbia and some areas of Alaska but the time of large numbers of takes off Baja California during "warm" PDO regimes.

Similarly, sightings of blue whales in NOAA's Platforms of Opportunity database from 1959 to 2006 show patterns supportive of a shift in blue whale occurrence coinciding with the PDO cycle. Sightings off Mexico and California to Oregon (25 of 27 and 19 of 21) or 92\% combined occurred during the "warm" PDO regime periods in contrast to the POP sightings for Washington, British Columbia, and the Gulf of Alaska (east of Kodiak Island), where all seven sightings occurred during "cold" PDO regime years. The proportion seen during warm or cold regimes for both Mexico and California-Oregon are significantly different than for Washington to the Gulf of Alaska (Fisher's exact test, $P<0.001$ in both cases). Sightings in the central North Pacific including northern waters west of Kodiak did not show a clear association with the PDO (six during cold regime years and eight during warm regime years). 
Whaling may well have influenced blue whale distribution by depleting populations but perhaps also by altering the extent to which blue whales needed to migrate farther north to meet food requirements. Certainly, the blue whale population was greatly reduced by commercial whaling and perhaps, with these reduced numbers, they were able to meet their energetic requirements in the period immediately after whaling with less of a need to migrate farther north. A recovery in the blue whale population or limitation in prey availability now may have prompted a shift by blue whales in the eastern North Pacific back to heavier use of more northern feeding areas.

\section{ACKNOWLEDGMENTS}

Funding for the surveys came from DFO Species-at-Risk and International Governance programs, Southwest Fisheries Science Center, and Michuru Ogino. Marine mammal observers on the SWFSC surveys in Alaska included C. Oedekoven, J. C. Salinas, H. Fearnbach, M. Richlen, R. Rowlett, B. Goodwin, S. Hakala, S. Rankin, L. Zele, A. Ligon, L. Carswell, K. Roberts, J. Redfern, B. Taylor, and L. Hoffman. Vessel support was provided by Captain Jan Bevlander and crew of the Curve of Time, and Captain Syd Webb and officers and crew of the CCGS John P. Tully. We thank the observers on the surveys British Columbia especially M. O. L. Spaven, H. Kimura, M. Webb, R. Abernethy, J. Huggins, and A. Calambokidis. A. Douglas and L. Schlender conducted the blue whale photographic identification matching, Randy Burke provided identification photographs of blue whale from 1997, R. Sears of MICS and D. Gendron of CICIMAR compared the identification photographs from British Columbia and Alaska to their catalogs from Mexican waters, and Gretchen Steiger reviewed and edited the manuscript. Helpful suggestions were provided by Andrew Trites, Paul Wade, and Tim Gerrodette. NOAA provided access to the Platforms of Opportunity database, thanks to Wendy Lewis for compiling these sightings. Dominique Camacho and Robin Abernathy assisted in preparation of figures.

\section{Literature Cited}

Acevedo-Gutierrez, A., D. A. Croll and B. R. Tershy. 2002. High costs limit dive time in the largest whales. Journal of Experimental Biology 205:1747-1753.

BARLOW, J. 1994. Abundance of large whales in California coastal waters: A comparison of ship surveys in 1979/80 and in 1991. Report of the International Whaling Commission 44:399-406.

BARLOW, J., AND K. A. Forney. 2007. Abundance and population density of cetaceans in the California Current ecosystem. Fisheries Bulletin 105:509-526.

Benson, A. J., AND A. W. Trites. 2002. Ecological effects of regime shifts in the Bering Sea and eastern North Pacific Ocean. Fish and Fisheries 3:95-113.

BRINTON, E., AND A. TOWNSEND. 2003. Decadal variability in abundances of the dominant euphausiid species in southern sectors of the California Current. Deep-Sea Research Part II: Topical Studies in Oceanography 50:2449-2472.

Brueggeman, J. J., G. A. Green, R. A. Grotedendt and D. G. Chapman. 1987. Aerial surveys of endangered cetaceans and other marine mammals in the northwestern Gulf of Alaska and southeastern Bering Sea. Report (unpublished) to the Minerals Management Service, Alaska OCS Office, and NOAA Office of Oceanography and Marine Assessment, Alaska Office. Available from National Technical Information Service PB89234652, available from http://www.ntis.gov.

Brueggeman, J. J., G. A. Green, R. W. Tressler and D. G. Chapman. 1988. Shipboard surveys of endangered cetaceans in the northwestern Gulf of Alaska. Report (unpublished) to the Minerals Management Service, Alaska OCS Office, and NOAA Office of 
Oceanography and Marine Assessment, Alaska Office. Available from National Technical Information Service PB89234660, available from http://www.ntis.gov.

Brueggeman, J. J., T. C. Newby and R. A. Grotefendt. 1985. Seasonal abundance, distribution and population characteristics of blue whales reported in the 1917 and 1939 catch records of two Alaska whaling stations. Report of the International Whaling Commission 35:405-411.

Calambokidis, J., AND J. Barlow. 2004. Abundance of blue and humpback whales in the eastern North Pacific estimated by capture-recapture and line-transect methods. Marine Mammal Science 20:63-85.

Calambokidis, J., G. S. Schorr, G. H. Steiger, J. Francis, M. Bakhtiari, G. Marshall, E. Oleson, D. GENDRON AND K. RoberTSON. 2007. Insights into the underwater diving, feeding, and calling behavior of blue whales from a suction-cup attached video-imaging tag (Crittercam). Marine Technology Society Journal 41:15-25.

Calambokidis, J., G. H. Steiger, J. C. Cubbage and K. C. Balcomb. 1989. Biology of blue whales in the Gulf of the Farallones and adjacent areas of California. Report by Cascadia Research (unpublished) to Gulf of the Farallones National Marine Sanctuary, San Francisco, CA. 58 pp. Abstract available at http://www.cascadiaresearch.org/ abstracts/abstract.htm\#bmCA89.

Calambokidis, J., G. H. Steiger, J. C. Cubbage, K. C. Balcomb, C. Ewald, S. Kruse, R. WELlS AND R. SEARS. 1990. Sightings and movements of blue whales off central California 1986-88 from photo-identification of individuals. Report of the International Whaling Commission (Special Issue 12):343-348.

Clapham, P. J., S. Leatherwood, I. Szczepaniak and R. L. Brownell, Jr. 1997. Catches of humpback and other whales from shore stations at Moss Landing and Trinidad, California. Marine Mammal Science 13:369-394.

Croll, D. A., A. Acevedo-Gutierrez, B. R. Tershy and J. Urbán-Ramierz. 2001. The diving behavior of blue and fin whales: Is diving duration shorter than expected based on oxygen stores. Comparative Biochemistry and Physiology A 129:797809.

Demaster, D. P., A. W. Trites, P. Clapham, S. Mizroch, P. Wade, R. J. Small and J. Ver HoEf. 2006. The sequential megafaunal collapse hypothesis: Testing with existing data. Progress in Oceanography 68:329-342.

Dohl, T. P., R. C. Guess, M. L. Duman And R. C. Helm. 1983. Cetaceans of central and northern California, 1980-1983: Status, abundance, and distribution. Report (unpublished) by the Center for Marine Studies, University of California, Santa Cruz, to Minerals Management Service, OCS Study MMS 84-0045. 284 pp. Available from National Technical Information Service PB85183861, http://www.ntis.gov.

Donovan, G. 1991. A review of IWC stock boundaries. Report of the International Whaling Commission (Special Issue 13):39-68.

Ford, J. K. B., K. Heise, L. G. Barrett-Lennard and G. M. Ellis. 1994. Killer whales and other cetaceans of the Queen Charlotte Islands/Haida Gwaii. Report by the Vancouver Aquarium (unpublished) to South Moresby/Gwaii Haanas National Park Reserve, Canadian Parks Service. 46 pp.

Forney, K. A., AND R. L. BROWNELL, JR. 1996. Preliminary report of the 1994 Aleutian Island Marine Mammal Survey. Working paper SC/48/O11 presented to the International Whaling Commission, June 1996, Aberdeen, Scotland.

Gilpatrick, J. W., JR., AND W. L. Perryman. 2008. Geographic variation in external morphology of North Pacific and Southern Hemisphere blue whales (Balaenoptera musculus). Journal Cetacean Research and Management 10:9-21.

Green, G. A., J. J. Brueggeman, R. A. Grotefendt, C. E. Bowlby, M. L. Bonnell and K. C. BALCOMB. 1992. Cetacean distribution and abundance off Oregon and Washington, 1989-1990. Page 100 in J. J. Brueggeman, ed. Oregon and Washington marine mammal and seabird surveys. Report (unpublished) by Ebasco Environmental, Bellevue, Washington, and Ecological Consulting, Inc., Portland, Oregon, for the Minerals 
Management Service, OCS Study MMS-912-0093. Available from National Technical Information Service PB93173755, http://www.ntis.gov.

Gregr, E. J., AND A. W. TRITES. 2001. Predictions of critical habitat for five whale species in the waters of coastal British Columbia. Canadian Journal of Fisheries and Aquatic Sciences 58:1265-1285.

Hyrenbach, K. D., AND R. R. Veit. 2003. Ocean warming and seabird communities of the southern California Current System (1987-98): Response at multiple temporal scales. Deep-Sea Research Part II: Topical Studies in Oceanography 50:25372565 .

Ivashin, M. V., AND A. A. Rovnin. 1967. Some results of the Soviet whale marking in the waters of the North Pacific. Norsk Hvalfangst-Tidende 57:123-129.

Leatherwood, S., R. R. Reeves, W. M. Perrin And W. E. Evans. 1982. Whales, dolphins, and porpoises of the Eastern North Pacific and adjacent waters. A guide to their identification. U.S. Department of Commerce, NOAA Technical Report NMFS Circular 444. 245 pp. Available from National Technical Information Service PB84135813, http://www.ntis.gov.

Mantua, N. J., And S. R. Hare. 2002. The Pacific decadal oscillation. Journal of Oceanography 58:35-44.

Mate, B. R., B. A. Lagerquist and J. Calambokidis. 1999. Movements of North Pacific blue whales during the feeding season off southern California and southern fall migration. Marine Mammal Science 15:1246-1257.

McDonald, M. A., J. A. Hildebrand And S. C. WebB. 1994. Blue and fin whales observed on a seafloor array in the Northeast Pacific. Journal of the Acoustical Society of America 98:712-721.

Nichol, L. M., E. J. Gregr, R. Flinn, J. K. B. Ford, R. Gurney, L. Michaluk and A. PEACOCK. 2002. British Columbia commercial whaling catch data 1908 to 1967: A detailed description of the B.C. historical whaling database. Candadian Technical Report of Fisheries and Aquatic Sciences 2396. iv $+76 \mathrm{pp}$.

Pike, G. C., AND I. B. MacAsKie. 1969. Marine mammals of British Columbia. Fisheries Research Board of Canada Bulletin 171:1-54.

Pyle, P., AND L. GilberT. 1996. Occurrence patterns and trends of cetaceans recorded from southeast Farallon Island, California, 1973 to 1994. Northwestern Naturalist 77:1-8.

RANKIN, S., J. BARLOW AND K. M. STAFFORD. 2006. Blue whale (Balaenoptera musculus) sightings and recordings south of the Aleutian Islands. Marine Mammal Science 22:708713

Reeves, R. R., S. Leatherwood, S. A. Karl and E. R. Yohe. 1985. Whaling results at Akutan (1912-1939) and Port Hobron (1926-1937), Alaska. Report of the International Whaling Commission 35:441-457.

Reilly, S. B., AND V. G. Thayer. 1990. Blue whale (Balaenoptera musculus) distribution in the eastern tropical Pacific. Marine Mammal Science 6:265-277.

RICE, D. W. 1963. Progress report on biological studies of the larger cetacea in the waters off California. Norsk Hvalfangst-Tidende 7:181-187.

RICE, D. W. 1966. Blue whales in the waters off Baja California. Report (unpublished) to the Scientific Committee of the International Whaling Commission.

Rice, D. W. 1974. Whales and whale research in the eastern North Pacific. Pages 170-195 in W. E. Schevill, D. G. Ray and K. S. Norris, eds. The whale problem. Harvard University Press, Cambridge, MA.

RICE, D. W. 1992. The blue whales of the southeastern North Pacific Ocean. AFSC Quarterly Report, Oct-Nov-Dec 1992, Alaska Fisheries Science Center, National Marine Fisheries Service, Seattle, WA.

Rice, D. W., AND A. A. Wolman. 1982. Whale census in the Gulf of Alaska, June to August 1980. Report of the International Whaling Commission 32:491-497.

Rondeau, J. H. 1987. The Farallon Islands 1542-1986, an ecosystem review. Unpublished report, P. O. Box 620458, Woodside, CA. 239 pp. 
Simmonds, J., AND D. MacLennan. 2005. Fisheries acoustics: Theory and practice. 2nd edition. Blackwell Science, Oxford, UK.

Smith, R. C., P. Dustan, D. Au, K. S. Baker and E. A. Dunlap. 1986. Distribution of cetaceans and sea-surface chlorophyll concentrations in the California Current. Marine Biology 91:385-402.

Springer, A. M., J. A. Estes, G. B. Van Vliet, T. M. Williams, D. F. Doak, E. M. Anner, K. A. Forney And B. Pfister. 2003. Sequential megafaunal collapse in the North Pacific Ocean: An ongoing legacy of industrial whaling? Proceedings of the National Academy of Sciences of the United States of America 100:12223-12228.

STAFFORD, K. M. 2003. Two types of blue whale calls recorded in the Gulf of Alaska. Marine Mammal Science 19:682-693.

STAFFORD, K. M., AND C. G. FOX. 1998. A comparison of the acoustic signals produced by blue whales (Balaenoptera musculus) in the North Pacific and their use in stock differentiation. Page 127 in Abstracts for the World Marine Mammal Science Conference, Monaco, 20-24 January 1998. Society for Marine Mammalogy, Lawrence, KS.

StAFFord, K. M., S. L. NieUKiRK AND C. G. Fox. 2001. Geographic and seasonal variation of blue whale calls in the North Pacific. Journal of Cetacean Research and Management 3:65-76.

Steiger, G. H., J. Calambokidis, J. C. Cubbage, K. C. Balcomb and P. Bloedel. 1989. Size and age class of blue and humpback whales in a central California feeding area. Page 64 in Abstracts Eighth Biennial Conference on the Biology of Marine Mammals, Pacific Grove, California, 7-11 December. Society for Marine Mammalogy, Lawrence, KS.

Stewart, B. S., S. A. Karl, P. K. Yochem, S. Leatherwood and J. L. Laake. 1987. Aerial surveys for cetaceans in the former Akutan, Alaska, whaling grounds. Arctic 40:33-42.

Sydeman, W. J., R. W. Bradley, P. Warzybok, C. L. Abraham, J. Jahncke, K. D. HyrenBACH, V. Kousky, J. M. Hipfner AND M. D. OHMAn. 2006. Planktivorous auklet Ptychoramphus aleuticus responses to ocean climate, 2005: Unusual atmospheric blocking? Geophysical Research Letters 33, L22S09, doi:10.1029/2006GL026736.

SZCZEPANIAK, I. D., AND M. A. WeBbER. 1985. Summer and autumn sightings of marine mammals in the Gulf of the Farallones, California 1983-1984. Report (unpublished) to Oceanic Society Expeditions, San Francisco, CA.

Thompson, P. O., AND W. A. FriedL. 1982. A long-term study of low frequency sound from several species of whales off Oahu, Hawaii. Cetology 45:1-19.

Trites, A. W., B. D. Volker, E. J. Gregr, J. K. B. Ford And P. F. Olesiuk. 2007. Killer whales, whaling and sequential megafaunal collapse in the North Pacific: A comparative analysis of the dynamics of marine mammals in Alaska and British Columbia following commercial whaling. Marine Mammal Science 23:751-765.

WADA, S. 1980. Japanese whaling and whale sighting in the North Pacific 1978 whaling season. Report of the International Whaling Commission 30:415-424.

WADE, L. S., AND G. L. FRIEDRICHSEN. 1979. Recent sightings of the blue whale, Balaenoptera musculus, in the northeastern tropical Pacific. Fisheries Bulletin 76:915-919.

Wade, P. R., V. N. Burkanov, M. E. Dahlheim, N. A. Friday, L. W. Fritz, T. R. Loughlin, S. A. Mizroch, M. M. Muto, D. W. Rice, L. G. Barrett-lennard, N. A. Black, A. M. Burdin, J. Calambokidis, S. Cerchio, J. K. B. Ford, J. K. Jacobsen, C. O. Matkin, D. R. Matkin, A. V. Mehta, R. J. Small, J. M. Straley, S. M. McCluskey, G. R. VAN Blaricom AND P. J. Clapham. 2007. Killer whales and marine mammal trends in the North Pacific - a re-examination of evidence for sequential megafauna collapse and the prey-switching hypothesis. Marine Mammal Science 23:766-802.

Webber, M. A., And S. M. CoOper. 1983. Autumn sightings of marine mammals and birds near Cordell Bank, California 1981-82. Cordell Bank Expeditions, Walnut Creek, CA (unpublished). $44 \mathrm{pp}$. 